\title{
Sparsely Granulated Somatotroph Adenoma
}

National Cancer Institute

\section{Source}

National Cancer Institute. Sparsely Granulated Somatotroph Adenoma. NCI Thesaurus.

Code C45926.

A growth hormone producing pituitary gland adenoma composed of small, round cells containing fibrous bodies and scarce, small secretory granules. 